\title{
O conceito de República nos primeiros anos do Império: a semôntica histórica como um campo de investipação das idéias políticas
}

Silvia Carla Pereira de Brito Fonseca*

Resumo: Neste artigo pretende-se analisar os distintos significados do conceito de República nas primeiras décadas do século XIX, enfatizando-se que o uso alternativo das diferentes acepções pela imprensa consistia em artifício retórico para persuadir os leitores da primazia dos governos eletivos e temporários. Para tanto, é avaliada a elaboração de "dicionários políticos", inseridos nas edições dos jornais, uma vez que a persuasão necessariamente incluía a reflexão acerca da mudança de significados para as mesmas palavras.

Palavras-chave: conceito de República - dicionários políticos - Brasil, século XIX.

* Pesquisadora Prodoc na Universidade do Estado do Rio de Janeiro - UERJ.

Anos 90, Porto Alegre, v. 13, n. 23/24, p.323-350, jan./dez. 2006 
O conceito de República nos primeiros anos do Império:

\section{Introdução}

A relação entre texto e contexto tem sido objeto de inúmeras reflexões no campo da história do pensamento político. Seguramente, essa tensão foi crucial para a renovação dos estudos entre as décadas de 1960 e 1970. O desenvolvimento da história conceitual verificado principalmente, mas não exclusivamente, na Alemanha ocorre entre 1972 e 1990, fruto do esforço da edição do monumental dicionário de conceitos históricos organizado por Otto Brunner, Werner Conze e Reinhart Koselleck (1972).

Idealizado a partir de uma revisão dos padrões tradicionais do estudo da história das idéias - Ideengeschichte -, como também da herança da filosofia da história presente na Geistesgeschichte, o dicionário procura relacionar a história conceitual à história política e social, tendo por fim fornecer análises contextualizadas dos conceitos, além da história de sua utilização, compreendendo um período que, embora remonte à antiguidade, realça a inflexão semântica dos conceitos entre 1750 e 1850.

Para tanto, os organizadores empreenderam uma crítica à polaridade estabelecida na análise conceitual entre as perspectivas materialista e idealista. Conforme essa visão, os conceitos não são vistos como redutíveis a reflexos da base material, nem tampouco como constituídos por padrões culturais nacionais. Ao contrário, são definidos como "construções intelectuais contestadas" em suas mudanças e permanências nas estruturas da sociedade. (Richter, 1990, p. 6).

De acordo com a sugestão metodológica formulada por Koselleck, torna-se imprescindível relacionar as mudanças conceituais, tomando por princípio dois aspectos: em primeiro lugar, a relação dialética entre conceitos e contexto, considerando que aqueles tanto registram quanto afetam as transformações políticas e sociais. Nessa medida, as mudanças são percebidas, 
registradas e classificadas numa determinada conjuntura histórica com base nas disputas acerca de seus significados. Em segundo lugar, a recuperação dos sentidos dos conceitos historicamente requer a análise dos aspectos sincrônicos e diacrônicos, a partir do relevo conferido à semântica enquanto elemento que possibilita a comunicação entre universos temporais distintos. Dito de outra forma, a alteração de significados para a mesma palavra evidencia que "toda sincronia contém sempre uma diacronia presente na semântica, indicando temporalidades diversas". (Koselleck, 1992,

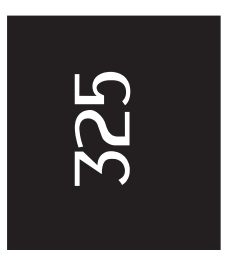
p. 141).

Por sua vez, a percepção das transformações nos modos de pensar e o universo conceitual no qual as idéias se movem implica numa metodologia que concebe como ponto de partida a palavra, vista como "vestígio" do historiador do pensamento político. Perseguir os objetivos da História conceitual envolve, portanto, o empreendimento de dois caminhos: a recuperação dos diferentes significados que o conceito comportava no período em questão, bem como a definição de sua especificidade em relação a épocas anteriores.

Assim, a investigação dos conceitos, a partir da exegese dos textos, alcança uma dimensão histórica, uma vez que as manifestações de permanência ou mudança, presentes num dado contexto político concreto, são compreendidas com base na aquisição da linguagem e na diversificação de sentidos.

Nessa medida, traduzir os registros passados das palavras para o nosso entendimento atual significa percorrer os conflitos políticos e sociais do passado em meio ao delineamento conceitual de sua época e, acima de tudo, a autocompreensão do uso da linguagem que fizeram os indivíduos no tempo. (Koselleck, 1979, p. 111). 
O conceito de República nos primeiros anos do Império:

\section{A República como um conceito}

Assim como ocorre à noção de democracia, a república - por definição uma forma de governo eletiva e temporária, cujo representante, singular ou coletivo, é escolhido pelos cidadãos de um corpo político - adquire ao longo dos séculos conotações diversas, apenas compreensíveis num determinado contexto conceitual.

Por conseguinte, a clássica tipologia de Aristóteles, incorporada pela posteridade, das formas de governo segundo o número de cidadãos que constituem a classe governante, ou o poder de um, de poucos, ou de muitos - monarquia, aristocracia, democracia - resultaria, em virtude de uma percepção cíclica do tempo, no predomínio de um elemento em prejuízo dos demais, em suas formas degeneradas - a tirania, a oligarquia, a oclocracia - respectivamente (Aristóteles, 2003, p. 105). Essas considerações, rapidamente alinhavadas, estariam na origem do enaltecimento da politeia aristotélica ou do governo misto no pensamento político ocidental, no qual o poder é partilhado entre todas as categorias ou grupos nos quais os cidadãos se dividem, o que significa que esta seria a forma menos propícia ao exercício do poder em benefício de um grupo limitado. ${ }^{1}$

Por democracia, Aristóteles pretendia um sistema no qual o poder, a despeito de ser largamente distribuído, era despoticamente exercido por homens não diferenciados entre si, um governo no qual todo o poder era controlado por maiorias numéricas. Como antítese criou a sua imagem da politeia, uma construção na qual as diferenças entre os homens seriam consideradas na distribuição de papéis políticos, bem como do poder. (Pocock, 1975, p. 173).

Entretanto, a Respublica romana promove uma inflexão na antiga tipologia grega, que realçava o princípio de governo, a archia, ao enfatizar a coisa pública, o bem comum, a comunidade. Nessa medida, Cícero acentua que os elementos distintivos da República 
seriam o interesse público e sobretudo a conformidade com uma lei comum, significado este que perduraria, em alguma medida, até o século XVIII. (Matteucci, 2000, p. 1109).

$\mathrm{Na}$ Idade Média, às denominações de regnum e civitas se sobrepôs a noção universalizante de Respublica Christiana em vista da ordenação da sociedade sob os dois poderes universais, a Igreja e o Império, cuja legitimação divina assimilava o governo dos homens às leis da natureza.

Nos primórdios da Idade Moderna, todavia, tanto a concep-

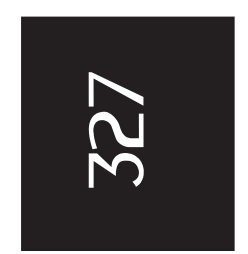
ção de república quanto o ideário republicano revestem-se de uma consciência política secular ao retomar o ideal da polis aristotélica enquanto um governo finito, localizado no tempo e no espaço. Por essa razão, um elemento vital da teoria republicana lastreava-se em idéias sobre a ocorrência de eventos contingentes, nos quais o tempo era a dimensão que conferia inteligibilidade às seqüências de sucessos particulares que compõem a História, constituindo-se numa forma original de historicismo (Pocock, 1975, p. 3). Nessa medida, a contraposição de uma perspectiva temporal e secular da História, ou seja, não sagrada porque não eterna, à noção cristã relacionava-se ao papel desempenhado pela política, ou à capacidade dos homens de enfrentar a contingência, a fortuna, por meio da virtude cívica.

Entretanto, conforme a visão da História associada ao Império, a sociedade seria compreendida como reflexo de uma ordem hierárquica presente no paraíso e na natureza, cuja legitimação e categorias de organização seriam eternas, concebida a mudança apenas enquanto degeneração. Assim sendo, o princípio subjacente à noção de Império, e de monarquia em geral, repousava numa associação ao eterno e imutável, ao passo que ao ideário republicano correspondia uma percepção diversa de tempo, finito e humano, em vista da disjunção entre a ordem política e a ordem natural. Afirmar a república, então, implicaria em quebrar a continuidade de um universo hierárquico em momentos particulares, 
O conceito de República nos primeiros anos do Império:

promovendo a particularização da História e sua secularização. (Ibidem, p. 54).

No século XVIII, no entanto, a despeito da perpetuação da centralidade da prevalência da lei e da Constituição como apanágio dos governos republicanos, seu significado torna-se mais complexo em razão da presença de princípios diversos na classificação das formas de governo. Segundo essa ordem de considerações, à tríade aristotélica - monarquia, aristocracia, democracia -, fundada num critério quantitativo e referida à elaboração de experiências históricas, sucede a tipologia moderna, alicerçada em princípios qualitativos, elaborada por Montesquieu a partir da herança de Maquiavel.

Conforme esse enfoque, à moderna tríade - monarquia, república (aristocrática ou democrática), despotismo - agregam-se fatores distintivos relativos à extensão dos territórios; à igualdade ou não dos cidadãos; à origem da formulação da lei; aos elementos constitutivos dos governos, como a honra, a virtude ou o medo.

Efetivamente, os três tipos de organização resumem-se, no âmbito da filosofia da História, a categorias temporais, uma vez que o conceito de Constituição se fundamenta na crença em uma separação consciente entre o espaço da experiência e o horizonte da esperança. Nessa medida, o próprio conceito de Constituição remeteria à conciliação entre o passado e o futuro. (Koselleck, 1979, p. 353).

De acordo com a mesma interpretação, o antigo conceito político mais amplo de respublica, compreendendo todas as formas de governo, adquire um caráter restrito de exclusividade, referido, porém, ao futuro. Por outras palavras, "um conceito utilizado histórica e teoricamente (...) saturado de experiências, se converte em um conceito de expectativa". (Ibidem, p. 354).

Assim, à mudança de significados para as mesmas expressões dentro de um dado contexto histórico corresponde a percepção de um sentido, um telos no espaço da ação política. Conforme 
assinala Koselleck, desde o século XVIII acentua-se a luta semântica para definir posições políticas ou sociais, o que confere aos conceitos, por si abstratos e polissêmicos, uma vez que reúnem a pluralidade da experiência, uma perspectiva temporal informada pela "teologia do progresso" que imprimiria sentido à mudança. (Ibidem, p. 190).

\section{História conceitual e grupos políticos no período regencial}

Parece ser uma obviedade afirmar que as palavras têm história. Todavia, o descaso com a história dos conceitos no âmbito da História política gera imprecisão e empobrecimento no estudo dos diferentes grupos e facções presentes no cenário político de um dado período.

Nessa perspectiva, situa-se o conhecido artigo de Paulo Pereira de Castro (1978, v. 2, t. II, p. 9-67) intitulado "A 'experiência republicana", no qual a expressão relaciona-se exclusivamente à elegibilidade do regente. De acordo com o texto, tomado como referência por boa parte da historiografia, Castro distingue os liberais moderados e os liberais exaltados não em função de uma disputa entre monarquistas e republicanos, mas em razão dos diferentes caminhos propostos por ambas as correntes para a obtenção de reformas políticas. Assim, após a deposição de Carlos X na França, ambas as vertentes passam a "admitir uma solução monárquica, $\mathrm{O}$ programa farroupilha praticamente se confunde com o dos monarquistas liberais se se põe de lado a deliberação (...) de alcançar as reformas desejadas através da revolução armada. Os demais - os moderados - até o último momento tenderão a contar com um ajuste pacífico" (ibidem, p. 9. Grifado pelo autor).

Entretanto, para além da diferenciação quanto aos métodos para atingir o mesmo objetivo - reformas com a manutenção da 
O conceito de República nos primeiros anos do Império:

monarquia -, Pereira de Castro introduz outra distinção. Sem enunciar, em momento algum, a presença de qualquer projeto político republicano, sugere uma divisão entre o que denomina de "linha nativista" e "linha de cor". Dessa forma, recorta o segmento farroupilha em "liberais puros de inspiração jeffersoniana (...) e agitador que toca nos ressentimentos de classe e de raça e acena com promessas de uma nova ordem social" (ibidem, p. 10. Grifos do autor). Ainda segundo Castro, o primeiro grupo seria representado por Antonio Borges da Fonseca e Teófilo Otoni, ao passo que o segundo teria em Cipriano Barata e no redator do periódico Nova Luz Brasileira, Ezequiel Corrêa dos Santos, seus principais expoentes.

Portanto, temos uma dupla clivagem: a primeira, sugerindo uma indistinção básica - todos seriam monarquistas após 1830 -, proposição difícil de sustentar, já que, em seguida à abdicação do imperador em 1831, amplia-se o número de periódicos que passam a propor abertamente a República enquanto forma de governo; e a segunda, ainda mais problemática, tendo em vista que, para Castro, tanto a "inspiração jeffersoniana" dos "liberais puros", quanto o suposto haitianismo do grupo "agitador" seriam perfeitamente compatíveis com os princípios monárquicos. ${ }^{2}$

Destarte, sugere-se que os periódicos publicados entre as décadas de 1820 e 1830 constituem um meio privilegiado para o estudo dos diversos grupos políticos, não apenas devido à redefinição semântica de conceitos, mas também em vista da apreensão do aspecto formativo do qual se revestia a imprensa na primeira metade do século XIX.

Os próprios redatores advertiam que o embate semântico traduzia a disputa política. Nessa direção, reclama o jornal republicano Voz Fluminense, em sua edição de 28 de janeiro de 1831, a necessidade do que chamou de um "novíssimo dicionário" em vista da mudança de significados atribuídos às mesmas palavras, revelando os conflitos políticos antes do 7 de abril. 


\section{A polissemia do conceito de república}

A noção de república compreende, entre a segunda metade do século XVIII e a primeira do século XIX, aos menos três significados: em primeiro lugar, como definição de um território submetido a uma autoridade comum, independente da forma de governo, de acordo com um registro típico do Antigo Regime. Conforme essa compreensão, pode-se tomar como exemplo a bela introdução de frei Caneca à conhecida "Dissertação sobre o que se deve entender por pátria do cidadão e deveres deste para com a mesma pátria" redigida no início de 1822. Assim, ao enaltecer o entendimento humano e associá-lo ao "fio de Ariadne" a conduzilo "no intrincado labirinto do mundo", o frade carmelita lembra que "em uma república bem constituída o primeiro cuidado do governo, a respeito dos cidadãos e súditos é procurar iluminá-los com as luzes da ciência, artes e ofícios". (Caneca, 2001, p. 55).

Em segundo lugar, o conceito de respublica também pode ser definido como a precedência do bem comum e a prevalência da lei e da Constituição. Segundo esse registro, adverte Antonio Borges da Fonseca no primeiro número de seu jornal O Republico, publicado no dia 2 de outubro de 1830, ao explicar sua denominação, assim como a epígrafe extraída do Contrato social: "Talvez haja alguém que não goste do título que tomei, e menos da epígrafe, não importa. A significação (...) mostra que eu só desejo o bem publico".

Em terceiro lugar, com base num sentido mais restrito, a noção de república igualmente comportava o significado de governo eletivo e temporário. De acordo com essa acepção e a despeito dos obstáculos impostos pela legislação, frei Caneca, após a deflagração da Confederação do Equador, se pronuncia em resposta ao Imperador, que clamava aos pernambucanos pelo abandono do que chamava de "sistemas políticos reprovados pelas lições da experiência", argumentando que "é inegável que em todo 
O conceito de República nos primeiros anos do Império:

o Brasil existe uma bem visível fermentação para se mudar a forma de governo"; a localização do Brasil "entre governos republicanos, (...) cooperava para que lançando fora o jugo português, aborrecessem aos Brasileiros para sempre testas coroadas, e procurassem um governo mais livre possível" (Typhis Pernambucano, $\mathrm{n}^{\circ} \mathrm{XXV}, 8$ de julho de 1824. Grifos no original).

Da mesma maneira, agregavam-se à noção de república, entre o último quartel do século XVIII e a primeira metade do século XIX, conceitos que recuperavam a rica polêmica do Novo Mundo, sobrepondo-se na América a Geografia à História, o futuro ao passado. Como lembra Antonello Gerbi,

"O orgulho americano nascia como louvor dos méritos físicos do país e não como ostentação de uma herança histórica (...). Os americanos não podiam vangloriar-se de seu passado colonial (...) mas do vigor fecundo da natureza circundante, fresca, viçosa, copiosa em todos os seus reinos que parecia prometer generosamente, ou mesmo garantir um desenvolvimento ilimitado". (Gerbi, 1996, p. 151).

Assim sendo, a consciência, historicamente determinada, do progresso envolvia a evocação de mitos e associações segundo as quais o "destino dos impérios curvava-se diante do curso do Sol", de leste a oeste, reservando à América um futuro radioso e o "encaminhamento irresistível para as formas republicanas de governo" (ibidem, p. 121).

Nesse sentido, associa Borges da Fonseca a república à regeneração do mundo inteiro ao censurar os princípios hereditários e evocar o famoso libelo de Thomas Paine:

"Se queremos a verdadeira liberdade, convém seguirmos os passos dos Estados Unidos (...) desprezando essas góticas instituições (...) porque enfim as idéias republicanas vão grassando com uma rapidez e força, que já mostra estar se 
aproximando o dia da restauração do mundo inteiro e do completo aniquilamento desses princípios hereditários, com os quais não se pode conciliar o senso comum". (O Republico, $\mathrm{n}^{\circ} 80,23$ de junho de 1831).

\section{Formas alternativas para designar a república na imprensa regencial}

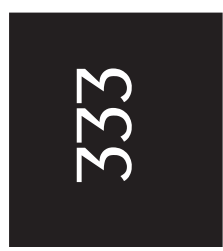

O período regencial, por sua vez, guardava em sua provisoriedade a possibilidade de um futuro a ser definido em meio à luta política. Todavia, o republicanismo, enquanto um "conceito de movimento", associava-se à noção de progresso, substituindo a experiência pela referência temporal e espacial, bem como pela idéia de infalibilidade do processo histórico que adquire uma lógica própria, vista como irreversível e independente da ação humana. Tal compreensão transparece desta passagem do jornal fluminense $O$ Tribuno do Povo, publicada em 24 de fevereiro de 1832: "É então que se verá baquear um sistema de Governo que não pode ser adotado na América. Ela não pode deixar de ser toda Republicana: é da natureza das coisas, há de acontecer infalivelmente".

As distintas classificações dos governos, "partidos" e suas finalidades, assim como a explicação dos conceitos, constituíam recursos que embora pudessem parecer triviais, adquiriram notável relevância, posto que valendo-se da etimologia para "definir" as formas de governo, visavam persuadir os leitores. O jornal fluminense $O$ Exaltado, redigido pelo padre e professor de retórica e gramática Marcelino Pinto Ribeiro Duarte, dedica boa parte de seus números a reveladoras tipologias dessa ordem.

Parece oportuno considerar que à época a palavra "partido" carregava uma conotação muito negativa, o que pode ser verificado não apenas pelos jornais, mas também pelo significado que lhe 
O conceito de República nos primeiros anos do Império:

emprestam os dicionários. Assim, de acordo com a primeira edição do léxico composto pelo padre Rafael Bluteau e reformado por Antonio de Moraes Silva, o vocábulo era compreendido como "parcialidades, partes, bando, facção" (Silva, 1789), interpretação esta que se mantém até a terceira edição de 1823, quando se acrescentam as seguintes acepções: "Entregar-se a partido (...), i. é, com certas condições; (...) \ Lei, natureza, condição (...) \ cometer partido, i. é, oferecer, propor meio de acomodação na demanda ou guerra \Fazer em seu partido, i. é, ser-lhe útil, favorável (...) \Estar de melhor partido, i. é, de melhor condição" (Silva, 1823). ${ }^{3}$

Inicialmente, situa o padre Marcelino, na divergência entre os "Partidos", a causa das comoções "que ora dilaceram a opinião pública no Rio de Janeiro; e talvez; o que Deus não permita, no Brasil todo". Propõe, então, a seguir sua primeira classificação:

“Três são os Partidos divergentes, que sensivelmente se têm manifestado nesta Corte (...). Um é dos Puritanos, por outro nome - os Exaltados -, os quais não querem contemplações e compadecimentos com o crime (...). O Segundo Partido é dos conhecidos Moderados - a quem os seus antagonistas chamam Hipócritas Jesuítas - Este partido, parece, por suas opiniões e fatos incontratáveis (sic) muito amigo do Governo (...). O terceiro Partido é dos que desejam Monarquia - eletiva temporária; estes são conhecidos - Republicanos". (O Exaltado, no 1, 4 de agosto de 1831).

Quanto às formas de governo, são identificadas apenas três, com base em critérios quantitativos: o "Governo Democrático", no qual "são reconhecidos 4 Poderes diferentes, residindo o Soberano no Povo; o qual distribui os poderes Parciais ou políticos, temporariamente, em seus escolhidos, residindo porém o Executivo em dois ou mais indivíduos escolhidos da massa da Nação. Tal foi o Governo de Roma nos primeiros tempos de sua república”. (Ibidem). 
O segundo tipo de governo arrolado é o "Aristocrático, em o qual a Nação está dividida em duas classes tão somente: Nobreza e Plebe". A primeira "reúne em si os Poderes Soberano e Político, que todos são exercitados temporariamente por certo número de escolhidos de entre si de uma maneira sempre despótica: e a Plebe é considerada com a condição desprezível de escravos sem direitos (...). Este Governo, parece, querem estabelecer agora no Brasil”. (Ibidem).

A terceira forma de governo é a monárquica, compreendida

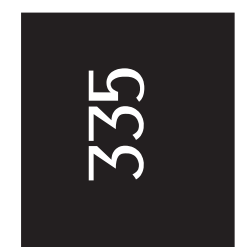
no sentido etimológico da palavra, na qual os poderes residem "em um só homem, com o título de Imperador, Rei, Ditador, Protetor, Autocrator, Czar, Doge, ou Presidente". Esse tipo de governo, entretanto, de acordo com o padre Marcelino, divide-se em três distintas modalidades, classificadas "por suas matérias em: despótico: Absoluto: e Legal”. (Ibidem).

No governo despótico "são desconhecidos os Poderes Soberanos e políticos; e o Povo, como um agregado de escravos ou autômatos, obedece cega e humildemente ao capricho e vontade de um tirano". O governo absoluto, ao contrário, reconhece a soberania e os demais poderes políticos, "porém todos residem em um Monarca, o qual manda fazer as Leis que regrem seu Estado. (...) Tal foi o Governo de Portugal, Espanha e França: dos quais este passou de absoluto a Legal; aqueles de absoluto[s] a despóticos". (Ibidem).

O Governo Legal é assim caracterizado por serem todos os membros da sociedade indistintamente submetidos às leis. Além disso, a soberania reside no Povo, não há classe privilegiada nos termos da lei, "o interesse público é a mola real que regula os atos de todos os Cidadãos (...) se chamou a semelhantes Estados, de duas palavras Latinas - res-publica - republica; e a seus Governos republicanos; ou Constitucionais". Destarte, a república é definida exclusivamente em função da precedência da lei e do bem comum. Por essa razão, o redator insere uma nova distinção: o 
O conceito de República nos primeiros anos do Império:

"Governo Legal, Republicano ou Constitucional, palavras que significam o mesmo", divide-se, "segundo a sua forma", em "Democrático" ou "Monárquico Misto".

Quanto ao Governo republicano democrático, é "aquele em o qual [são] distribuídos os Poderes Competentemente: o Executivo é exercitado temporariamente por muitos", não é recomendado pelo redator para o país, de vez que

"os poderes se conservam promíscuos entre as autoridades e o Povo. O melhor, portanto, dos Governos republicanos é o Monárquico misto. Isto é Governo em [ilegível] de sua Soberania, elegendo os Delegados dos poderes políticos: muitos para fazer a Constituição e as Leis, Um só para executar e fazer cumprir as Leis; o qual, por exercitar ele só as funções do Executivo (...) de duas palavras Gregas que correspondem às Latinas Solus principatas: se chamou Monarca: e o Estado Monárquico Constitucional ou republicano". (Ibidem).

No entanto, as "monarquias constitucionais republicanas", tendo-se em vista o princípio eletivo, também se dividem em três tipos: hereditárias, vitalícias ou temporárias, "conforme a vontade expressa na Constituição pelo poder Soberano". Convém atentar aqui para a peculiar compreensão dos conceitos de "monarquia" e "república", conforme esclarece o professor de retórica.

Assim sendo, a primeira modalidade, considerada contrária ao direito natural e passível de degenerar em Monarquia Absoluta ou Despótica, é a "Monarquia republicana hereditária (...) aquela em a qual a Constituição do Estado estabelece o Direito de sucessão na família do Monarca, uma vez eleito, chamada Dinastia". (Ibidem).

A segunda forma de "monarquia republicana" é a vitalícia, "aquela em que o chefe executivo, uma vez eleito, preside, rege ou impera a Nação e exerce os poderes conferidos durante sua vida; e

Anos 90, Porto Alegre, v. 13, n. 23/24, p.323-350, jan./dez. 2006 
por sua morte, a Nação reassume a delegação de sua Soberania e transmite a outro Monarca (...) qualquer outro Cidadão, se a Nação quiser. Esta Monarquia parece-me a mais conforme com a boa ordem e interesse do Brasil".

A terceira espécie de "monarquia republicana" é a temporária, ou seja, aquela em que o

"Chefe Executivo é eleito (...) pelo tempo de uma legislatura, que pode ser de 2, 4, 6 ou mais anos. (...) Este Governo é o mais natural e legítimo e o melhor, se os Povos não são prejudicados pelos prestígios da realeza e se têm as virtudes necessárias, principalmente a do Patriotismo; o que por desgraça do Brasil, eu não descubro na massa dos Brasileiros, divididos em partidos (...) e educados para viverem debaixo da infame tirania. (...) O Monarca, ou vitalício ou temporário, pode ter indistintamente o título de Rei; Protetor; Provedor, Presidente; Cônsul; Regente; Chefe Supremo; ou o que a Nação lhe quiser dar, menos, porém o de Imperador (...) que a palavra latina Imperator (...) é o mesmo que - o mandatário absoluto". (Ibidem).

Para se ter uma idéia da originalidade do expediente retórico do qual se valera o redator do periódico, conviria cotejar com os significados emprestados pelos dicionários de então aos conceitos de "monarquia" e "república". Assim sendo, as definições que se repetem ao menos nas seis primeiras edições do léxico de Moraes Silva denotavam a "república" como: "o que pertence e respeita ao público de qualquer estado, v. g. convém à República que todos trabalhem. \Estado que é governado por todo o povo ou por certas pessoas; $\int$ a República das Letras, i.e., os homens letrados". Constam também termos correlatos como "Republicano" ou "que vive na República. \Que aprova o governo das Repúblicas"; e ainda "Repúblico" que seria entendido como aquele que fosse "zeloso do bem público" (Silva, 1789) ${ }^{4}$. No entanto, a edição de 1858, apesar de reproduzir as mesmas expressões e significados, registraria 
O conceito de República nos primeiros anos do Império:

"novos" conceitos como "Republicanismo" ou "qualidade de republicano" e "Republicida", ou seja, "pessoa que destrói uma república". (Silva, 1858).

Já o dicionário de Luiz Maria da Silva Pinto, impresso em 1832 e que habitualmente resumia os verbetes do léxico de Moraes Silva, interpretaria a "República" como um "Estado governado por certas pessoas autorizadas pelo povo; o que pertence ao público de qualquer Estado. República das Letras. Os Literatos”. (Pinto, 1832).

Já o conceito de monarquia seria compreendido nas seis edições mencionadas do Moraes como "o Estado governado por um só Chefe ou Soberano. \O governo de um Chefe, oposto à Democracia, Aristocracia, Oligarquia" (Silva, op. cit.). Luiz da Silva Pinto definiria a "monarquia" como "governo de um só Príncipe. O Estado governado por um só Príncipe”. (Pinto, 1832).

\section{Formas de defender a república}

Assumir publicamente através de artigos na imprensa a defesa da república como forma de governo era considerado crime previsto tanto pelo Código Criminal de 1830, quanto pelo Código de Processo de 1832, além de ser inconstitucional.

Entre os inúmeros recursos para amparar princípios republicanos, o mais freqüente era a transcrição de artigos de outro periódico. Motivados, algumas vezes pela polêmica, outras simplesmente pela afinidade de propósitos, lançava-se mão, em geral, de folhas de outras províncias com o intuito de demonstrar a extensão dessas idéias, ou mesmo para eximir-se da responsabilidade legal sobre os princípios apregoados.

O jornal Voz Paulistana, promovido pelos estudantes do curso de Direito de São Paulo, cuja redação é atribuída a Francisco Bernardino Ribeiro, parece ser o mais citado pelos periódicos 
fluminenses, secundado pelo também paulista O Observador Constitucional, que circulava desde 1829, e que no início da Regência era ainda conhecido pela associação ao médico e jornalista italiano Giovanni Baptista Líbero Badaró, assassinado, como se sabe, em 1830.

Assim sendo, a folha exaltada fluminense Nova Luz Brasileira, em sua edição de 2 de julho de 1831, recorre à Voz Paulistana para enaltecer repetidamente o governo dos Estados Unidos, país que "em 52 anos, de meio milhão de habitantes pass[a] a contar 11 milhões de Cidadãos venturosos", e conclamar os "Povos do Universo" à guerra às "tiranias e monarquias (...). O momento insta (...) tiranos abandonai os tronos, retirai-vos. Povos constituí-vos REPUBLICANAMENTE”. (Grifado no original).

Num tom mais "racional", a Nova Lu₹ Brasileira comenta, em 15 de setembro do mesmo ano, artigo do Observador Constitucional no qual é demonstrado "matematicamente que a República no Brasil é inevitável (...). Desta proposição tira o Observador uma ilação mui clara de filantropia e tino político; diz ele aos portugueses negociantes que não façam guerra aos federalistas Republicanos e nem se fiem em Auroras e Diarios do Governo que mudam de rumo em lhe saltando o vento pela proa".

Também O Republico de Antonio Borges da Fonseca parecia ser leitor assíduo da Voz Paulistana, transcrevendo freqüentemente seus artigos. Assim ocorre em 19 de fevereiro de 1831, ao louvar o "governo virtuoso" dos Estados Unidos: "um governo nacional eletivo [que] não tem outros interesses separados dos da Nação (...) fundado sobre a igualdade perfeita e, em uma palavra, federativo, onde cada província sendo livre em se governar por si, fazer as suas leis [e] nomear seus magistrados". (Grifado originalmente. Transcrição da Voz. Paulistana, no 4, 25 de janeiro de 1831).

Alguns redatores, notadamente Ezequiel Corrêa dos Santos, da Nova Luz Brasileira, e João Baptista de Queiroz, escritor da folha Jurujuba dos Farroupilhas e, posteriormente, da Matraca dos 
O conceito de República nos primeiros anos do Império:

Farroupilhas, recorriam a Silvestre Pinheiro Ferreira para sustentar suas proposições, citando o Curso de Direito Publico Interno e Externo, publicado na França em 1830.

O elemento que tomavam de empréstimo ao publicista português naturalmente não se referia à apologia ao governo republicano, mas à ênfase conferida em sua obra à representação política, consubstanciada na instituição de um "Poder Eleitoral", assim como a crítica aos privilégios, tidos como incompatíveis com qualquer sistema constitucional. ${ }^{5}$

De acordo com Silvestre Pinheiro, para estabelecer a "grande reforma" que requer a transição da monarquia absoluta para a constitucional seria necessário "preparar os ânimos da geração futura (...) [e] refundir os princípios da jurisprudência constitucional", tarefa para a qual se volta, segundo suas palavras, no Manual do cidadão em um governo representativo, publicado em 1834. (Ferreira, 1998 , v. 2, t. III, p. X/XI).

Contudo, a referência a Silvestre Pinheiro talvez possa ser tomada como um expediente retórico de recurso à autoridade, porquanto não se deve esquecer que a despeito de asseverar no prólogo do Manual do Cidadão que "não pode admitir outra forma de governo que não seja a de uma monarquia livre de todo o privilégio", enfatiza, alguns parágrafos adiante, que "a maior parte dos povos tem posto por condição a reforma das suas constituições políticas a manutenção do privilégio da perpetuidade da coroa. Tal julgamos nós ser a vontade das nações a cujas assembléias constituintes oferecemos este nosso trabalho; e portanto era forçoso adotarmos aquela exceção à lei comum, como um dos princípios fundamentais do presente projeto". (Ibidem, p. XI/XII).

Entretanto, a precedência conferida à monarquia eletiva e a redefinição semântica da palavra democracia, que passa a ser sinônimo de ausência de privilégio, são apropriadas pela Nova Luz Brasileira como equivalentes à apologia de mandatários revogáveis e temporários. 
Silvia Carla Pereira de Brito Fonseca

"Felizmente o Snr. Silvestre Pinheiro, no seu Curso de Direito Público (...). Não haja receio das eleições da monarquia eletiva, diz o egrégio publicista Pinheiro, naqueles países (...) onde não há nenhum privilégio, onde não há nenhuma aristocracia (...). Cuidavam os publicistas que havia incompatibilidade entre a democracia e a monarquia, esquecidos de que o monarca é, ou deve ser, um Presidente vitalício; de que a palavra democrático não denota senão a ausência de todo o privilégio, sem o que não há governo representativo constitucional (...). A Nova Luz quer que o Povo Brasileiro fique certo, uma vez para sempre, que não deve confiar em mandatário, cujo poder não é revogável e temporário". (Nova Luz Brasileira, no 152, 9 de julho de 1831).

Igualmente, ampara-se O Jurujuba dos Farroupilhas em Silvestre Pinheiro, tendo por fim a defesa do direito da Nação, "verdadeiro soberano", de revogar mandatos, uma vez que todos os funcionários públicos seriam mandatários. "A Nação pode retirar ao monarca a delegação que lhe conferiu; e num Estado é a Nação competente para julgar se lhe convém fazer essa mudança". As repúblicas bem organizadas, diz Silvestre Pinheiro, em nada são inferiores a uma monarquia democrática, sendo esta bem organizada. Nenhum Povo deve confiar senão em Mandatários revogáveis, e se há inconvenientes na mudança dos Empregados, diz o mesmo publicista, há maior perigo em conservar os que são maus, sobretudo se o são por natureza e força das coisas. Os Reis, diz ele, são Presidentes vitalícios; e os Governos militares, ou teocráticos, são essencialmente aristocráticos, e conduzem a uma monarquia bárbara e despótica. (O Jurujuba dos Farroupilhas no 9, 6 de outubro de 1831. Grifos no original).

Ainda seria possível inscrever como recurso para louvar a República a transcrição pela folha Nova Luz Brasileira de uma passagem do Antigo Testamento na qual os judeus pedem a Samuel que lhes designe um rei, para que se assemelhassem aos povos vizinhos. A negativa do profeta, assim como seus argumentos, 
O conceito de República nos primeiros anos do Império:

também foram inseridos por Thomas Paine no segundo capítulo do libelo republicano Senso comum (1982, p. 17/18), publicado em 1776, o que suscita a hipótese do redator fluminense haver copiado o trecho do panfletário inglês, embora assegurasse que não recorreria mais a publicistas para "dizer aos Brasileiros o que é um monarca ou imperador".

Não obstante, deve-se notar que Rousseau no Contrato Social (2003, p. 88/89), editado pela primeira vez em 1762, aludira à passagem bíblica ${ }^{6}$ que, por sua vez, já havia sido comentada por Algernon Sidney no século anterior em sua obra Discurso sobre o Governo ${ }^{7}$ publicada em 1698. Parece, portanto, fora de dúvida que o episódio fosse narrado por sucessivas gerações, tendo em vista a defesa do governo republicano.

Igualmente, convém observar que a leitura da Bíblia deveria ser corrente entre os segmentos letrados à época, além de constituir-se em poderoso recurso suasório, o que não impede, todavia, que a inspiração do jornal fluminense para citar o extrato bíblico não tenha provindo da leitura do Contrato Social ou mesmo do Senso comum. A propósito, essa mesma passagem já havia sido mencionada por Borges da Fonseca na folha Abelha Pernambucana, editada em Recife em 1829. Seria interessante notar, no artigo da Nova Luг, a constante preocupação do redator em estabelecer analogias com os sucessos do Império do Brasil.

Disse Ele [o profeta Samuel] ao seu Povo quando este the pediu um rei (...) Fizeste um mal diante do Snr. pedindo um rei sobre vós (...) O rei tomará vossos filhos para conduzirem as suas carroças; fará deles moços de cavalos, que vão correndo diante de seus coches (...). Fará de vossas filhas, a umas suas perfumadeiras, a outras suas cozinheiras, a outras suas padeiras. Tomará também o que houver de melhor nos vossos campos, nas vossas vinhas, nos vossos olivais: e da-lo-á aos seus servos. Far-vos-á pagar o dízimo de vossos trigos, e do rendimento de vossas vinhas para ter que dar 
aos seus eunucos, e aos seus oficiais (a Câmara aprovou o grande tratamento dos criados do Minino (sic) Imperador!!!!) Tomar-vos-á os vossos servos e vossos escravos (...) e falos-á trabalhar para ele. Tomará também o dízimo dos vossos rebanhos e vós sereis seus servos. Naquele dia clamarei vós (sic) sobre o vosso rei que vós mesmo escolheste (sic), e o Senhor vos não ouvirá naquele dia, porque vós mesmo pedistes que se vos desse um rei. (Tal nos aconteceu e pior com o Pedro de Bragança e Bourbom [sic])". (Nova Luz Brasileira, no 178, 6 de outubro de 1831. Grifos no original).

Entretanto, o meio mais comum utilizado pelos jornais para enaltecer a república era, indiretamente, por meio da desqualificação da monarquia, seus atributos, protocolos e rituais, como "a adulação de irem buscar o Imperador debaixo do Palio". Conforme sugeria Borges da Fonseca, a obediência emana da autoridade da lei, portanto,

"a Assembléia geral deve proibir rigorosamente um tal abuso, [pois] o Imperador é homem como nós (...). Também outro abuso vil, baixo e só digno de gente escrava é o de beijar a mão do Imperador (...). E muito mais insultante é o atrevido costume de apear-se um cidadão, ou de descer do carro, ou de ficar em pé quando passa o Imperador ou algum príncipe ou princesa. Deve-se já largar tal abuso". ( $O$ Republico, no 40, 19 de fevereiro de 1831).

A cerimônia de beijar a mão do Imperador também era acoimada de "costume turco" pela Voz Fluminense, periódico basicamente constituído por correspondências. Transcrevendo a carta possivelmente de um leitor que assinava como O Macaco que não gosta das macaquices Lusitanas, afirma o jornal, em 2 de dezembro de 1830, que tal costume 
O conceito de República nos primeiros anos do Império:

"bem se colhe que ele é impróprio de Povos Americanos livres, que por isso devem acabar com a modinha das Cortes Orientais. Na mesma Europa desmoralizada pelo governo da tirania (...) só a Espanha, como herdeira dos maus costumes turcos, foi quem por Lei injusta mandou seguir essa zumbaia maometana. Visto que sendo como é vênia profunda, um sinal de humildade e confissão de fraqueza (...) parece mais razoável que só diante da Divindade e da Nação soberana sejam os Povos e seus chefes obrigados a fazer as tais vênias profundas".

$\mathrm{Na}$ mesma direção seguiam os comentários de Cipriano Barata que denominava de

"cerimônia ridícula que os reis conservam para ostentarem sua representação de senhor, pretendendo que o povo não perca o hábito de os respeitar ao menos nesses exteriores. Todavia, não toquei na segunda parte da cerimônia, a qual é ajoelhar. Repara neste servilismo; ajoelhar é cerimônia que só pertence a Deus (...) e não a uns mortais, quase sempre os mais viciosos, ignorantes e criminosos da Sociedade". (Sentinella da Liberdade na sua primeira guarita, a de Pernambuco, onde hoje brada Alerta!, no 35, 26 de setembro de 1835).

Censurada também sistematicamente e apodada de "princípio europeu" era a concessão de títulos e honrarias, prática a qual d. Pedro recorrera com freqüência ${ }^{8}$, mas que no entanto fora suspensa ao longo da Regência.

“Ontem leu-se na Câmara dos Deputados o projeto [ilegível] um artigo que diz que a Regência pode dar títulos. A ser assim, ainda se pretende que no Brasil da América hajam títulos? É-me estranho tal pretender, e eu suponho que é melhor que de hoje avante a nossa legislação vá sendo concorde com o que devemos ser daqui a 8 ou 16 anos, pois mais tempo não se pode demorar o completo 
aniquilamento dos princípios da velha Europa cá na América”. (O Republico, nº 64, 10 de maio de 1831. Grifado no original).

Da mesma sorte, o jornal O Tribuno do Povo recriminava a Câmara dos Deputados por pretender restabelecer a concessão dos títulos e condecorações:

"O que são entre nós os Marquês de Paranaguá, o Conde

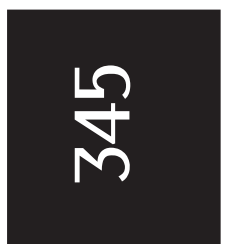
do Rio Pardo, o Barão Fulano \& c.? São lixo, são piores que lama, não valem nada porque o Brasil não quer cá títulos feudais e faz tanto caso de um Marquês e toda a comitante (sic) caterva, como faz de um cão morto (...). Ordens fora, fora títulos, valha o homem pelo que é na realidade não pelo que quer valer com fitas \& c.". (O Tribuno do Povo, $\mathrm{n}^{\circ}$ 40, 23 de junho 1831).

Conclusivamente, caberia reiterar que além desses recursos, os redatores empregavam expedientes retóricos que visavam, além da persuasão dos leitores, evitar perseguições e processos judiciais, servindo-se da polissemia dos conceitos. A propósito, seria oportuno lembrar o relevo atribuído à etimologia pelos próprios redatores dos periódicos pesquisados tendo em vista a compreensão das diversas acepções conferidas aos conceitos de República e Monarquia, determinando-se equivalências semânticas e expressões correlatas.

Conforme essa visão, deve-se realçar que não seriam reunidos à época no mesmo conceito atributos e qualificações que poderiam apresentar-se como dados a priori. Como parece esclarecer a classificação de governos e glossários inscritos nos jornais, a idéia de monarquia seria muitas vezes dissociada da hereditariedade, assim como da vitaliciedade, compreendendo-se a palavra como o governo exercido por um indivíduo, o que distanciava-se dos registros dos dicionários editados naquele momento. Da mesma maneira, a República seria descrita em algumas passagens como 
O conceito de República nos primeiros anos do Império:

um sistema político no qual precede a lei e o bem comum. Daí a utilização da aparentemente absurda expressão "monarquia republicana" que tanto poderia ser eletiva, hereditária, temporária ou vitalícia.

Assim sendo, a menção à "monarquia eletiva", "monarquia americana" ou mesmo sui generis constituía-se na fórmula para designar alternativamente a República como forma de governo. Tais diferenciações de significado, valendo-se do sentido etimológico das palavras, consistiam, por conseguinte, em artifícios para amparar a defesa de governos eletivos e temporários.

Não obstante, foi possível entrever que, ao menos no que pertence à idéia de república nas primeiras décadas do Império do Brasil, agregou-se a este conceito uma perspectiva de tempo linear que, embora não fosse exclusiva naquele contexto, não mais comportaria a tradição do equilíbrio institucional das forças políticas, mas seria enleada ao futuro, ou nos termos de Koselleck, transformar-se-ia num conceito de movimento.

Semelhante percepção temporal adquirira contornos definidos pelo claro e reiterado sentimento de ruptura com o passado, constantemente designado por "três séculos de escravidão". Tal distinção parece ter se revestido historicamente, entretanto, de uma dimensão não apenas temporal, mas também espacial, identificando-se na América a fórmula de sobrevivência das repúblicas no tempo, a partir do deslocamento semântico dos conceitos constitutivos do secular ideário republicano. É mister sublinhar que não se constatou nas fontes consultadas uma concepção que sugerisse qualquer forma de hierarquização entre as repúblicas americanas no período, mas sim uma visão de mundo ordenada a partir do preceito que conferia ao ocidente um futuro radioso.

Assim a "América", reunindo num conceito a um só tempo uma peculiar idéia de natureza e uma singular experiência histórica, delinearia tanto os desígnios políticos do país quanto a compreensão dos conceitos, referidos a um "novo" espaço de 
experiência. Por essa razão, parece possível afirmar que as reflexões e reivindicações relativas à república federativa fundamentaram o ideário republicano, em vista da precedência conferida à geografia, ou seja, à localização do Brasil na América, particularizada pela especificidade do continente americano, concepção esta legatária da polêmica sobre o Novo Mundo.

Por fim, parece plausível aduzir um outro aspecto na avaliação semântica dos conceitos políticos nesse momento. Trata-se da apreensão do caráter híbrido da linguagem política, ao revelar, por

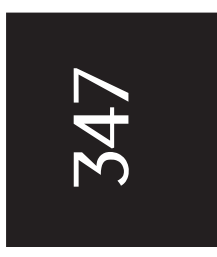
meio da disputa acerca dos significados das palavras, o conflito entre diversos tempos históricos, refundindo-se o passado e o presente em vista da construção do futuro, o que afinal assinalaria a especificidade do período.

Recebido em 15/09/2005.

Aprovado em 03/01/2006.

The concept of Republic in early Empire: historical semantics as a field of research on political ideas

Abstract: The purpose of this article is to study the polysemy of the notion of republic at the first decades of the nineteenth century, underlining the use of rhetoric devices by the press aiming at supporting the Federative Republic in Brazil. Therefore, the making of "political dictionaries" is analyzed, for persuasion inevitably involved thinking over the change in the meaning of the words.

Key words: notion of republic - political dictionaries - Brazil, nineteenth century.

\section{Notas}

${ }^{1}$ Sobre a Politeia aristotélica, ver Sérgio Cardoso (2000, p. 27-48).

${ }^{2}$ Não se sugere que a distinção entre liberais exaltados e liberais moderados decorra de uma simples disputa entre princípios republicanos e monárquicos, mas considerar esses grupos monoliticamente significa ignorar a rica polêmica presente na imprensa regencial.

${ }^{3}$ As edições de 1831 e 1858 repetem estas mesmas definições.

${ }^{4}$ As edições de 1813, 1823, 1831, 1844 e 1858 repetem este verbete.

Anos 90, Porto Alegre, v. 13, n. 23/24, p.323-350, jan./dez. 2006 
O conceito de República nos primeiros anos do Império:

${ }^{5}$ O Curso de Direito Publico não foi encontrado para a consulta. Por essa razão, optou-se pela leitura do Manual do cidadão em um governo representativo. A análise do "Poder Eleitoral" encontra-se na sexta conferência, v. 1, t. I, p. 100.

6 "Reconheço que supondo os súditos sempre inteiramente submissos, o interesse do príncipe seria então que o povo fosse poderoso, a fim de que, sendo esse poder o seu, o tornasse temido por seus vizinhos, mas, como esse interesse é apenas secundário e subordinado, e as duas suposições incompatíveis, é natural que os príncipes dêem sempre preferência à máxima que lhes é mais imediatamente útil. É o que Samuel expôs, com vigor, aos hebreus; é o que Maquiavel fez ver com evidência. Fingindo dar lições aos reis, deu-as, e grandes, aos povos. O príncipe de Maquiavel é o livro dos republicanos".

${ }^{7}$ Algernon Sidney, Discourses Concerning Government. Ver www.constitution.org/as/ dcg_000.htm, capítulo 3, seção 3: "Samuel did not describe to the Israelites the glory of a free Monarchy; but the Evils the People should suffer, that he might divert them from desiring a King".

8 "Ao menos com relação à Ordem de Cristo (...) dela se serviu às vezes mais abundantemente do que o próprio D. João VI, pois em nenhum dos anos do reinado deste se fabricaram no Brasil mais comendadores e cavaleiros como, por exemplo, no ano de 1825, em que sua safra foi, respectivamente, de 41 e 368, sem falar em uma grã-cruz". (Holanda, 1976, v. 1, t. II, p. 32).

\section{Fontes e referências bibliográficas:}

Periódicos:

Abelha Pernambucana, Pernambuco, 1829-1830.

O Exaltado: Jornal Litterario, Politico e Moral, Rio de Janeiro, 1831-1833.

Jurujuba dos Farroupilhas, Rio de Janeiro, 1831.

Nova Luz Brasileira, Rio de Janeiro, 1829-1831.

O Republico, Rio de Janeiro, 1830-1832.

Sentinella da Liberdade na sua primeira Guarita, a de Pernambuco, onde hoje brada Alerta! Recife, 1835.

O Tribuno do Povo, Rio de Janeiro, 1830-1832.

Typhis Pernambucano, Recife, 1824.

Voz Fluminense, Rio de Janeiro, 1829-1831.

Anos 90, Porto Alegre, v. 13, n. 23/24, p.323-350, jan./dez. 2006 


\section{Silvia Carla Pereira de Brito Fonseca}

Livros:

ARISTÓTELES. A politica. São Paulo: Martins Fontes, 2003.

BOBBIO, Norberto; MATTEUCCI, Nicola; PASQUINO, Gianfranco. Dicionário de política. Brasília: Editora da UNB; São Paulo: Imprensa Oficial do Estado, 2000.

BRUNNER, Otto; CONZE, Werner; KOSELLECK, Reinhart. Geschichtliche Grundbegriffe: Historisches Lexicon zur politish-sozialen Sprache in Deutschland. Stuttgart: Klett-Cotta, 1972.

CANECA, Frei Joaquim do Amor Divino. "Dissertação sobre o que se deve entender por pátria do cidadão e deveres deste para com a mesma pátria", Coleção Formadores do Brasil, organização de MELLO, Evaldo Cabral de. São Paulo: Editora 34, 2001.

CARDOSO, Sérgio. Que república? Notas sobre a tradição do 'governo misto'. In: BIGNOTTO, Newton (org.). Pensar a República. Belo Horizonte: Ed. UFMG, 2000 .

CASTRO, Paulo Pereira de. A 'experiência republicana', 1831-1840. In: HOLANDA, Sérgio Buarque de (org.). História Geral da Civilização Brasileira. São Paulo: Difel, 1978.

FERREIRA, Silvestre Pinheiro. Manual do cidadão em um governo representativo. Brasília: Senado Federal, 1998. 3v.

GERBI, Antonello. O Novo Mundo: história de uma polêmica (1750-1900). São Paulo: Companhia das Letras, 1996.

HOLANDA, Sérgio Buarque de. A herança colonial - sua desagregação. In: (org.). História Geral da Civilização Brasileira. São Paulo: Difel, 1976.

KOSELLECK, Reinhart. Uma História dos conceitos: problemas teóricos e práticos. Estudos Históricos, Rio de Janeiro: Editora da Fundação Getúlio Vargas, 1992.

1979.

Futuro pasado: para una semántica de los tiempos históricos. Barcelona: Paidós,

PAINE, Thomas. O senso comum e a crise. Brasília: UnB, 1982.

PINTO, Luis Maria da Silva. Diccionario da lingua brasileira. Ouro Preto:

Typographia de Silva, 1832.

Anos 90, Porto Alegre, v. 13, n. 23/24, p.323-350, jan./dez. 2006 
O conceito de República nos primeiros anos do Império:

POCOCK, John Greville Agard. The Machiavellian moment: florentine political thought and the Atlantic Republican tradition. Princeton: Princeton University Press, 1975.

RICHTER, Melvin. Reconstructing the History of Political Language: Pocock, Skinner, Geschichtliche Grundbegriffe. History and Theory, Middletown, n.29, v. $1,1990$.

ROUSSEAU, Jean-Jacques. O contrato social. São Paulo: Martins Fontes, 2003.

SILVA, Antonio de Moraes. Diccionário da lingua portuguesa ... $4^{\mathrm{a}}$ ed. Lisboa: Imprensa Régia, 1831.

Diccionário da lingua portuguesa ... $6^{\mathrm{a}}$ ed. Lisboa: Typographia de Antonio Jose da Rocha, 1858.

Diccionário da lingua portuguesa .... $5^{\mathrm{a}}$ ed. Lisboa: Typographia de Antonio Jose da Rocha, 1844.

Diccionário da lingua portuguesa ....2 ed. Lisboa: Typographia Lacerdina, 1813. Rio de Janeiro: Cff. Da s.a. Litho-Typ. Fluminense, 1922. Edição facsimilar, $2 \mathrm{v}$.

Diccionário de lingua portuguesa, composto pelo padre D. Rafael Bluteau, reformado e accrescentado por Antonio de Moraes Silva. Lisboa: na officina de Simão Thaddeo Ferreira, 1789.

Internet

www.constitution.org/as/dcg_000.htm 